

\title{
Meet a Member: Eric Nyberg, Releasing Materials Science into the Wild
}

\section{By Francine Garrone}

Hunkered down since before dawn on a colorful blanket of leaves covered by an early frost, Eric Nyberg prepares to draw back the string of his die-cast magnesium bow. Less than 25 feet from him stands a six-point bull elk. The orange glow of the sun rising above the mountains in eastern Washington illuminates the massive size of the elk and brings it into Nyberg's focus. He waits for the perfect moment and releases the arrow-success.

Nyberg, a senior research scientist at the Pacific Northwest National Laboratory in Richland, Washington, has been hunting for nearly 30 years in the state of Washington, and has taken deer and elk from several northwest states. His love for the nature-oriented sport has earned him two places in the Pope \& Young Club Bowhunting Big Game Records of North America record book.

"I began hunting as a teenager in Washington State," he said. "In eastern Washington, hunting, fishing, and other outdoor activities are very popular due to the open expanses, beautiful mountains, and abundant wildlife."

Prior to 2003, Nyberg did most of his hunting during rifle season. It wasn't until then that he was able to draw a "Non-Resident" elk hunting permit ("tag") for the state of Montana and became interested in archery hunting. "Drawing the tag was going to be a hunting opportunity I would not miss, only problem was that it occurred during the rifle hunting season in Washington State," he said. "Therefore, I decided to take up archery hunting." Nyberg said he practiced with his new bow all summer and within the first month of becoming an archer he landed a six-point bull elk in Washington State. That same year he used the coveted "Montana tag" to take another six-point bull elk with a rifle. Since then, he has hunted exclusively with a bow and arrow.

"I love hunting because it is a chal-

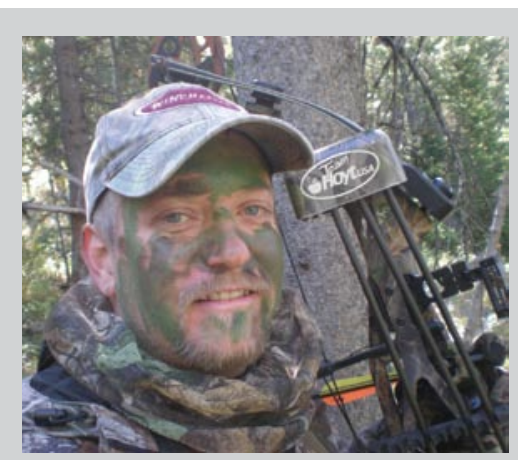

Figure 1. Eric Nyberg prepares for a day of elk hunting in the wooded mountains in eastern Washington.

lenge-you versus nature," he said. "It is an opportunity to enjoy the outdoors in solitude while at the same time attempting to defeat oftentimes extreme odds."

According to Nyberg, the average success rate for archery elk hunting is about 20 percent. However, with extreme practice and many hours afield the odds increase, and in his case, reach 50 percent or higher. But even when an archer's odds of successfully shooting an elk are low, the real reward is the time spent alone deep in thought. "You can enjoy the sights, the smells, and the sounds of the forest and mountains," Nyberg said. "When the sun rises and you are looking at a 12,000 foot mountain in the distance with snow-encrusted glaciers glowing orange with the day's new sun, you really have to just sit back and enjoy those moments."

Even though hunting is an activity rarely associated with a laboratory, it does have a materials science aspect to it. Nyberg, who is past chairman of the Magnesium Committee, has drawn on his materials science background and incorporated it into his hunting experiences.

"Certainly as a metallurgist with a keen interest in lightweight materials, I searched for the bow that combined hunting and materials technology," he said. "I found a very nice bow made of die-cast magnesium that has served me very well! Fiber optic technology provides sights that can be used under very low light conditions and carbon fiber arrows that are strong as steel are all areas of materials interest to the engineer." Nyberg said even the clothes he wears are advanced materials, providing carbon assisted scent prevention.

Nyberg proudly displays proof of his deer and elk hunting successes throughout his home. "Every animal I have taken during my hunting adventures I have made the most of," he explains. "The meat is processed and nothing beats an elk steak with a glass of red wine and pepperoni and cheese while watching a football game." The animal hides are tanned and used for decoration or craft projects such as book covers, he said. The largest of his trophies are mounted on the wall for display and include "Rudolph" and "Randolph," the two six-point elk he took the year he drew the Montana tag.

For Nyberg, hunting is a chance not only for him to do something he has enjoyed since a teenager, but also a chance to spend time with his oldest daughter and enjoy nature. "I hunt with my eldest daughter, Hanna, who has hunted deer for five years and successfully took her first deer at the age of 13," he said. "For me, the opportunity to take part in a sport such as bowhunting offers the opportunity to enjoy nature at its best-wild and undisturbed. The passion I have for the sport is something I have passed on to my children and hopefully will to my grandchildren someday."

Each month, JOM features a TMS member and his or her activities outside of the realm of materials science and engineering. To suggest a candidate for this feature, contact Francine Garrone, JOM news editor, at fgarrone@tms .org. 